\title{
IDENTIFICATION OF SPECIES AND FATTY ACID COMPOSITION OF MICROALGAE FROM RAAS BEACH SENDANG BIRU MALANG AND THEIR POTENTIAL AS BIODIESEL FEEDSTOCK
}

\author{
${ }^{1}$ Eli Hendrik Sanjaya ${ }^{*},{ }^{1}$ Alifah Novitasari, ${ }^{1}$ Parlan, ${ }^{1}$ Laurent Octaviana, \\ ${ }^{1}$ Dermawan Afandy ${ }^{2}$ Sitoresmi Prabaningtyas. \\ ${ }^{1}$ Departement of Chemistry, Universitas Negeri Malang $(U M)$ \\ ${ }^{2}$ Departement of Biology, Universitas Negeri Malang (UM) \\ E-mail: eli.hendrik.fmipa@um.ac.id.
}

Received 22 Pebuari 2017

Accepted 9 April 2017

\begin{abstract}
Biodiesel is one of the best renewable energy made from triglycerides. Microalgae has a high lipid content include triglycerides, so it can be used as raw material for biodiesel production. Malang has many of beaches which are potent to become sources of microalgae, several beaches are surrounding Sendang Biru. The aims of this research were to identify the species of microalgae from Raas Beach Sendang Biru, determine their yield of lipid and fatty acid composition, and analyse their potential to became feedstock of biodiesel production. This research consists of five stages: identification of microalgae, cultivation, harvesting, determination of the yield of microalgae lipid by soxhlet extraction method, and analysis of the fatty acid composition of lipid by GC-MS. The results showed that the species of microalgae are dominated by Euglena sp and small amount of Gloeocapsa. The lipid yield of dried microalgae is $7.5 \%$ and the fatty acids composition are dodecanoic acid (1.6\%), tetradecanoic acid (1.3\%), hexadecanoic acid (16.6\%), 9,12-octadecadienoic acid (25.2\%), 9-octadecenoic acid (29.8\%), and octadecanoic acid (6.7\%). Based on this results, it can be concluded that the microalgaes from Raas Beach Sendang Biru are potential to become biodiesel feedstock but it still need optimization.
\end{abstract}

Keywords: biodiesel, fatty acid, microalgae, Raas Beach Sendang Biru, transesterification.

\section{Introduction}

Indonesia is a maritime country with $70 \%$ more parts in the form of water. However, the exploration potential and the natural resources in Indonesia is still focused on the potential that exists on the mainland. Exploration on the mainland has been greatly exaggerated and even uncontrolled and eventually many deforested landscape, forest fires, and floods. It's time to discover the potential of the maritime area. Recently, Indonesian Government has also committed to improve and explore the potential of Indonesian maritime territory.
Not only inland waters but marine waters in Indonesia also has a huge potential. The exploration that has been done in the ocean is still focused on making fish and seaweed. The results showed that the marine life is very potential to be developed is often referred to as microalgae or fitopankton.

Since the 1980s microalgae has been used in various fields but it is still not optimal. Microalgae have been widely used in the field of animal husbandry, waste processing, pharmaceutical and food supplements, and alternative energy sources as biodiesel, and many others [1]. 
Some strains of microalgae could produce hydrocarbons, for example Botryococcus sp. can produce long-chain hydrocarbons, C23-C40, such as n-alkadiena and nalkenes. Among some of these benefits, the very urgent use to develop is microalgae as an a source of alternative energy.

One of the alternative energy from renewable raw materials that is very possible and potential to be developed in Indonesia is biodiesel. There have been many studies on making biodiesel from various sources such as palm oil and jatropha seed oils [2,3]. Nonetheless oil palm cultivation can harm the environment, according [4], a palm oil plantation, covering millions of hectares of land in Southeast Asia, where the plantation of this kind have been directly or indirectly functional shifted tropical rain forests and resulted in loss of habitat for species such as rhinos and orangutans and the loss of carbon stored in the trees and the peat soils. Thus it is need to look for alternative sources of other raw materials.

Microalgae is eukaryotic or prokrariot photosynthetic microorganisms that can grow rapidly and live in harshly environment for microorganisms of simple unicellular or multicellular [5]. As an example for the prokaryote is Cyanobacteria (Cyanophyceae), while the eukaryotes are green algae (Chlorophyta) and diatoms (Bacillariophyta). According to Davis, vegetable microalgae are microorganisms that live floating around in the water and have no power relative motion so their existence is influenced by the movement of water and be able to photosynthesize [6].

Many microalgae have high contain of oil. There are some microalgae which has a high oil content, such as Schizochytrium sp. and Botrycoccus braunii has an oil content of up to $75 \%$ by weight of dried microalgae [7]. Oil from microalgae chemically similar to other plant oils that can certainly be a source of raw material for making biodiesel [8]. In addition to having a high oil content, microalgae also has a growth rate that is much faster than other oil sources because microalgae are short generation of living organisms [1]. In general, microalgae can improve their biomass doubled in just 24 hours. Even in the phase of exponential growth of microalgae is very fast, they can grow to be doubled within 3.5 hours.

Another advantage of the utilization of microalgae as a source of raw material for making biodiesel is the ability of microalgae to photosynthesize. As photosynthetic plants, microalgae is more efficient than terrestrial plants and an efficient candidate in the fixation of $\mathrm{CO}_{2}$ [8]. Microalgae are microorganisms that grow well in the water, but the results showed that microalgae can grow better in sea water than in freshwater [9].

As a maritime country, Indonesia has a very large marine areas. One area that has a lot of beaches that are located in Southern Malang, there have 18 beaches [10]. The beach area in South Malang has great potential as a source of microalgae with excellent characteristics, such as high $\mathrm{CO}_{2}$ fixation ability and contain a lot of oil. One of the potential beaches is Blue Spring Beach because this beach is the most crowded activity of beach compared to the others so that the air contains is more $\mathrm{CO}_{2}$. Thus hopefully on the beach Blue Spring has indigen microalgae that has both the ability to $\mathrm{CO}_{2}$ fixation and high content of lipids.

The process of making biodiesel is done through a transesterification reaction using catalysts. Transesterification reaction or an alcoholysis reaction also turn on an ester alcohol with another alcohol by a process similar to the process of hydrolysis. Alcohol substitutes are used as a substitute either for research purposes or industrial alcohol is methanol because it is the cheaper one [11]. The using of catalyst can be a chemical catalyst (acid or base) or a biocatalyst (enzyme lipase). The reaction in the biodiesel production process using lipase enzymes occurs gradually and in the 
form of equilibrium as in the following illustration [12].

$$
\begin{aligned}
& \mathrm{TG}+\mathrm{ROH} \leftrightharpoons \mathrm{DG}+\mathrm{R}^{\mathrm{I}} \mathrm{COOR} \\
& \mathrm{DG}+\mathrm{ROH} \leftrightharpoons \mathrm{MG}+\mathrm{R}^{\mathrm{II}} \mathrm{COOR} \\
& \mathrm{MG}+\mathrm{ROH} \leftrightharpoons \mathrm{Gly}+\mathrm{R}^{\mathrm{III}} \mathrm{COOR}
\end{aligned}
$$

Based on the reactions that occur in the process of making biodiesel, the potential microalgae as a feedstock of biodiesel production is the microalgae which has a high lipid content of the good fatty acid composition.

\section{Experimental}

\section{Equipment and materials}

\section{Procedure}

\section{Microalgae identification}

Species identification of microalgae in this research used the morphology test. This identification is carried out in the Laboratory of Microbiology Department of Biology, University of Malang by using the brand Olympus microscope with a magnification of $400 \mathrm{x}$. Microalgae picture are identified by size, shape, colour, and the presence of flagella.

\section{Microalgae Cultivation and Harvesting}

Microalgae cultivation is done in a container $(6 \mathrm{~L})$ with Walne media. In this research, cultivation was done by semicontinuous system. Microalgae are given light from the lamp as a light source and should be aerated for photosynthesis process. Microalgae are harvested with filtration method and dried using an oven with a temperature of $80^{\circ} \mathrm{C}$.

\section{Extraction of microalgae lipid}

Dried microalgae is extracted by by Soxhlet extraction method using n-hexane p.a. as solvent at $70^{\circ} \mathrm{C}$. Furthermore, a rotary evaporator is used to concentrate the lipid. Determination the yield of Lipids that have been obtained is determined by the following equation.

$$
\text { Randemen lipid }(\%)=\frac{\text { Mass of microalgae lipid }}{\text { mass of dry microalga }} \times 100 \%
$$

\section{Transesterification}

Transesterification was used for sample preparation before it was analysed with GC-MS. Lipid microalgae added with methanolic $\mathrm{NaOH}$ and shaken using a vortex for 30 seconds. Then, put it into the bath with a temperature of $95^{\circ} \mathrm{C}$ for 5 minutes. The solution was cooled and added with a BF3 solution and shaken until mixed using a vortex. Furthermore, the solution put back in the bath with a temperature of $100^{\circ} \mathrm{C}$ for 30 minutes. The solution was cooled, added hexane p.a,. and shaken and then allowed to stand a few moments to form two layers. The top layer is taken to be analyzed by GC-MS.

\section{GC-MS analysis}

Analysis of microalgae lipid profile is done using GCMS brand Agilent Technologies. A total $1 \mu \mathrm{L}$ sample is injected into the injector. GCMS run with a carrier gas such as helium with HP-5MS column with a column length of $30 \mathrm{~m}$, a diameter of 0.25 , temperature of $170^{\circ} \mathrm{C}$ oven and detector temperature $90^{\circ} \mathrm{C}$.

\section{Result and Discussion}

Microalgae Identification

In this research, the identification of microalgae was done by morphology test. The study was conducted using a microscope with a magnification of $400 \mathrm{x}$. Identification was done by comparing or matching with the literature Algae, Anatomy, Biochemistry, and Biotechnology and Freshwater Algae of North America. The results showed that the identification of microalgae derived from the Raas Beach Sendang Biru Malang propose dominated by Euglena sp (Fig. 1) and little of Gloeocapsa (Fig. 2).

\section{Harvesting of Microalgae}

Microalgae has been harvested and then put into oven to remove moisture contained. Drying is done to obtain a constant weight. In this research, dried microalgae which has been gained as much as $5.203 \mathrm{~g}$. 
Extraction of Lipids Microalgae

Dried microalgae obtained was extracted to get a lipid. Extraction was done by Soxhlet Extraction with using nhexane as the solvent. Selection of nhexane solvent based base on the characteristic of n-hexane as nonpolar molecule which is expected to dissolve nonpolar organic compounds contained in the dried microalgae. The results of the lipids is weight of $0.39 \mathrm{~g}$ (Fig. 3). So the lipid yield of dried microalgae is $7.5 \%$.

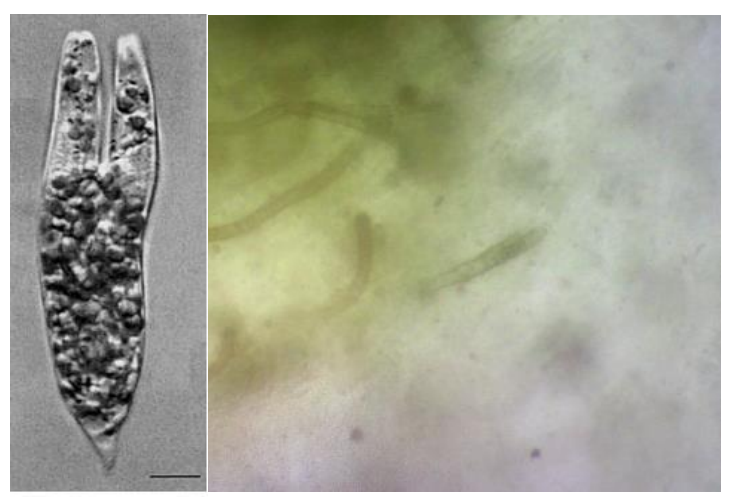

(a)

(b)

Figure 1. Euglena sp. a) Euglena sp. from Library (Algae, Anatomy, Biochemistry, and Biotechnology (12) dan b) Euglena sp Raas Beach Sendang Biru

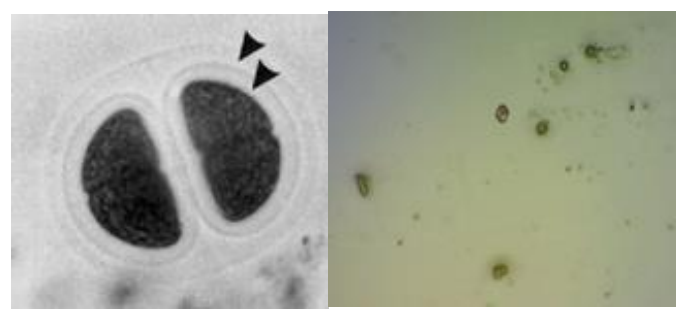

(a)

Figure 2. Gleocapsa a) Gloeocapsa from Library (Freshwater Algae of North America Ecology and Classification : 2) dan b) Gloeocapsa from Raas Beach Sendang Biru Malang

\section{GC-MS Analysis of Microalgae Lipid}

Fatty acid identification used GC-MS instrument. For preparing lipid sample, lipid was transesterified by using methanol as a reactan and $\mathrm{BF} 3$ as catalyst. Transesterification results was injecteted to GC-MS machine. The data obtained showed that 20 peaks but there are only 6 peaks including fatty acid methyl ester contained in microalgae lipid. Fig. 4 is a chromatogram result of transesterified lipids of microalgae.

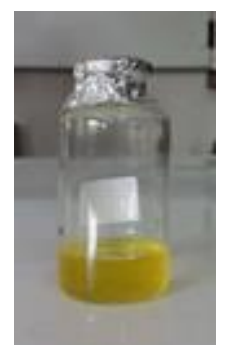

Figure 3. Lipids of Microalgae

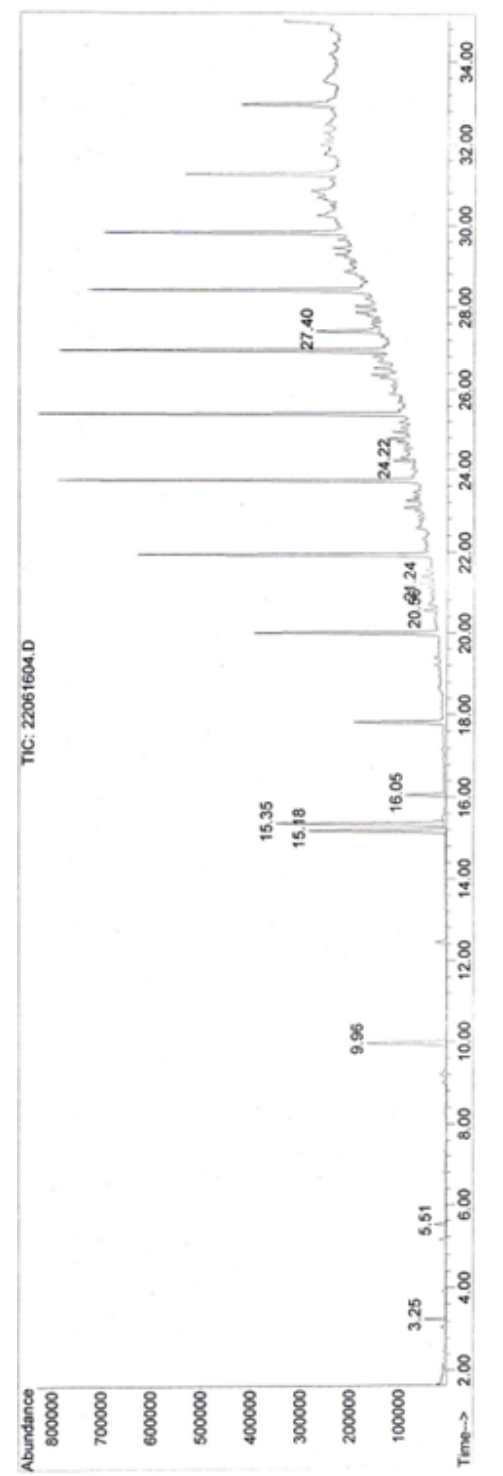

Figure 4. Chromatogram of lipid microalgae 
The analysis results showed that the fatty acids of microalgae lipid consist of dodekanoat acid (1.6\%), tetradekanoat acid (1.3\%), heksadekanoat acid (16.6\%), acid-oktadekadienoat $9.12(25.2 \%)$, acid 9- Oktadekenoat (29.8\%), and octadecanoic acid (6.7\%). According to Diaz et al, medium chain fatty acids (C16 and $\mathrm{C} \mathrm{18)}$ are considered ideal for the production of good quality of biodiesel [13]. The results showed that the levels of medium-chain fatty acids with $\mathrm{C} 16$ contained in microalgae sample obtained for $16.578 \%$ and $6.720 \%$ for $\mathrm{C} 18$. Moreover, the lipid yield of dried microalgae is $7.5 \%$. it is still lower than the lipid content in palm oil or others source of lipid. It indicates that the microalgae from Raas Beach Sendang Biru Malang are potential to become biodiesel feedstock but it still needed optimization. Optimization can be conducted by exposure the light source with the sun light directly because in this research the light source was lamp that might be the intensity and the wave length were not good enough

\section{References}

Benemann, J. R., 2008, Opportunities and Challenges in Algae Biofuels Production A Position Paper: in line with Algae World 2008.

Suhartanta and Arifin, Z., 2008, Pemanfaatan Minyak Jarak Pagar Sebagai Bahan Bakar Alternatif Mesin Diesel. Jurnal Penelitian Saintek, 13, 19-46.

Satriadi,H., Nafiega, F., Widayat, W, and Dipo, R., 2014, Peningkatan Kualitas Dan Proses Pembuatan Biodiesel Dari Blending Minyak Kelapa Sawit (Palm Oil) Dan Minyak Kelapa (Coconut Oil) Dan Bantuan Gelombang Ultrasonik. Media Komunikasi Ilmu dan Profesi Bidang Kerekayasaan, 35,

Supraniningsih, J., 2012 Pengembangan Kelapa Sawit Sebagai Biofuel dan Produksi Minyak Sawit Serta Hambatannya. Jurnal Widya, 29, 321. for the photosinthehtic process in microalgae.

\section{Conclusions}

The results showed that based on the morphology test, the microalgae contained on the Raas Beach Sendang Biru Malang are dominated by Euglena sp. manifold and little of Gloeocapsa. The yield of lipid produced from the dried microalgae extraction is $7.5 \%$. The fatty acids of microalgae lipid consist of dodekanoat acid $(1.6 \%)$, tetradekanoat acid $(1.3 \%)$, heksadekanoat acid $(16.6 \%)$, acidoktadekadienoat $9.12(25.2 \%)$, acid 9Oktadekenoat $(29.8 \%)$, and octadecanoic acid (6.7\%). It indicate that the microalgae from Raas Beach Sendang Biru Malang are potential to become biodiesel feedstock but it still needed optimization.

\section{Acknowledment}

The authors thank to Ministry of Research, Technology and Higher Education as the source of research fund.

Mata, T., M., Martins, A., A., and Caetano, N., S., 2010, Microalgae for biodiesel production and other applications: A review. Elsevier. 14, 217-232.

Rahardjo, D. Mikroalga Sumber Energi Alternatif Masa Depan, (Online), 2008, (http://forumbebas.com/thread37216.html, acceesed on June $3^{\text {th }}$ 2009).

Chisti, Y., 2007, Biodiesel from microalgae. Biotechnology Advances. Elsevier: 25, 294-306.

Sheng-Yi Chiu., 2009 Lipid accumulation and $\mathrm{CO}_{2}$ utilization of Nannochloropsis oculata in response to $\mathrm{CO}_{2}$ aeration, Bioresource Technology, 100, 833838.

Maschek, J. A. and Baker, B. J., 2008 Algal Chemical Ecology. Springer. Germany: Verlag Berlin Heidelberg. 
Sabri, F. 18 Wisata Pantai di Malang. 2014. (http://fotowinara.com/18wisata-pantai-di-malang/, accessed on March 31 ${ }^{\text {st }}$ 2015).

Ognjanović, N.D., Šaponjić,S.V., Bezbradica, D. I., and Knežević, Z. D., 2008, Lipase-Catalyzed Biodiesel Synthesis with Different Acyl Acceptors. APTEFF, 39, 1-212.
Balat, M., 2007, Production of Biodiesel from Vegetable Oils: A Survey. Energy Sources, Part A: Recovery, Utilization, and Environmental Effects. 29, 895913.

Diaz, G. C., Cruz, Y. R., Fortes, M.M., Viegas, C. V., Carliz, R. G., Furtado, N. C. and Aranda, D. A. G., 2014 Primary separation of antioxidants (unsaponifiables) the wet biomass microalgae chlamydomonas $\mathrm{sp}$ and production biodiesel.6, 1210-1218. 